Doğan, Y. (2020). Süreç temelli yazma eğitiminin bir boyutu olarak "hazırlık”. Ana Dili Eğitimi Dergisi, 8(2), 326342.

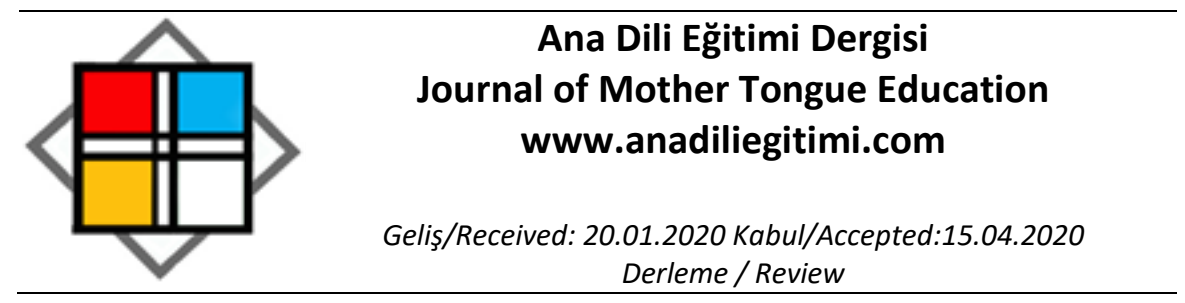

\title{
Süreç Temelli Yazma Eğitiminin Bir Boyutu Olarak “Hazırlık”
}

\author{
Yusuf DOĞAN*
}

\begin{abstract}
Öz
Yazma, yoğun ve uzun süreli çalışmalar yaparak geliştirilebilen bir dil becerisidir. Süreç temelli yazma, bu yoğun ve uzun süreli çalışmaları içeren, dikkatin ürüne değil sürece yoğunlaştırıldığı bir yaklaşımdır. Bu araştırma, süreç temelli yazma eğitiminin ilk basamağı olan "hazırlık"ın önemini ve bu aşamada yürütülecek çalışmaların ayrıntılarını ortaya koymayı amaçlayan nitel bir çalışmadır. Bu amaç çerçevesinde, araştırmada alanyazın taraması ve doküman incelemesinden yararlanılmıştır. Bu kapsamda öncelikle yazma becerisinin niteliği üzerinde durulmuş, ardından süreç temelli yazma yaklaşımı tanıtılmıştır. Daha sonra bu sürecin ilk basamağı olan "hazırıı" aşaması; "konu belirleme, konu üzerinde düşünme ve fikir üretme, konuyu sınırlandırma ve yazma amacı belirleme, yazı türünü belirleme ve hedef kitleyi belirleme" yönleriyle ele alınmıştır. Süreç temelli yazmanın ilk aşaması olan hazırlı̆ın, bütün yönleriyle ayrıntılı bir şekilde ele alındığında, yazma sürecinin diğer aşamalarını da olumlu yönde etkileyeceği ve hızlandıracağı söylenebilir.
\end{abstract}

Anahtar Kelimeler: süreç temelli yazma, hazırlık süreci, hazırlık ilkeleri, yazma eğitimi

\begin{abstract}
Writing is a language skill that can be developed by doing intensive and long-term studies. Processbased writing is an approach that includes these intense and long-term studies, where attention is focused on the process, not the product. This research is a qualitative study aiming to reveal the importance of "preparation", the first step of process-based writing instruction, and the details of the studies to be carried out at this stage. In this research, literature review and document analysis are used for this purpose. In this context, first of all, the quality of writing skill is emphasized, and then process-based writing approach is introduced. Then, the "preparation" phase, which is the first step of this process, are handled in terms of determining the topic, thinking and generating ideas on the topic, limiting the topic and determining the purpose of writing, determining the type of text and determining the target audience. Preparation, which is the first stage of process-based writing, is considered to affect other aspects of the writing process positively, and accelerate them when discussed in detail.
\end{abstract}

"Preparation" as a Dimension of Process-Based Writing Approach

Keywords: process-based writing, preparation process, principles of preparation, teaching writing

\section{Giriş}

Her türlü iletişim faaliyetinde bir araç olarak kullanılan dil; dinleme/izleme, konuşma, okuma ve yazma becerilerini içinde barındırır. Bu becerilerden dinleme/izleme ile okuma, anlama becerilerini; konuşma ve yazma ise anlatma becerilerini oluşturur. Çocuklar dinleme/izleme ile konuşmayı örgün eğitim öncesinde belirli bir düzeyde de olsa edinirler. İlkokul birinci sınıfın başından itibaren de okuma ve yazma öğrenme süreci başlar ve birey, bu dört beceriyi hayatı boyunca etkileşim içerisinde her ortamda kullanır.

\footnotetext{
* Doç. Dr., Gazi Üniversitesi Gazi Eğitim Fakültesi Türkçe ve Sosyal Bilimler Eğitimi Bölümü Türkçe Eğitimi Ana Bilim Dalı, Ankara, ydogan@gazi.edu.tr, ORCID: 0000-0001-8384-9808
} 
Hem sözlü hem de yazılı anlatım çalışmalarındaki temel amaç çocuklara; gördüklerini, yaşadıklarını, duyduklarını, düşündüklerini doğru, amaca uygun ve güzel bir biçimde anlatma becerisi kazandırmaktır (Kavcar, Oğuzkan ve Sever, 1997: 70). İlkokuldan üniversiteye hangi düzeyde yapılırsa yapılsın yazma çalışmaları; duyma, düşünme, duyup düşündüklerini yazıyla anlatma gibi söz konusu bu yetileri kazandırırken aynı zamanda kişiliğin dokusunu da meydana getirir (Özdemir, 1967: 5). Dolayısıyla "yazma", sadece bir dil becerisi olarak ele alınmamalı, kişiliğin oluşumu ve gelişmesi için gerekli bir unsur olarak da değerlendirilmelidir.

Yazmanın; hayatı anlamak, anladıklarımız üzerinde düşünmek ve başkalarını düşündürmek, ele alınan konu üzerinde derinleşmek, o konunun yeni boyutlarını keşfetmek, bütün bunları sahip olunan dile hâkimiyet ölçüsünde planlı bir biçimde ifade etmek gibi çok yönlü imkânları da bulunmaktadır (Ağca, 1999: 109). Burada özellikle vurgulanan husus yazma-düşünme ilişkisidir. Flower ve Hayes'e (1981: 366) göre yazma, içinde bir dizi farklı düşünce sürecini barındırır ve yazarlar bu süreci tıpkı bir orkestra şefi gibi yönetirler. İç içe geçmiş pek çok alt boyutun olduğu bu süreçte kendi düşüncelerini oluşturma, ortaya koyma işi; yazıyı yazan kişinin bilgi birikimi tarafından yönlendirilir. Dolayısıyla bir yazıyı oluşturmak çok da kolay değildir ve aynı zamanda bilgi birikimi gerektirir.

Yazma, öğrenciler açısından özel ve değerli bir faaliyet olmasının yanında onlara benzersiz bir öğrenme ortamı da oluşturur. Çünkü bir sürecin yaşandığı, bu sürecin sonunda da bir ürünün ortaya çıktığı yazma faaliyeti, bu yönüyle bazı etkili öğrenme stratejilerine denk özelliklere sahiptir (Emig, 1977: 122). Yazma becerisinin söz konusu bu yönlerinin, eğitim faaliyetlerinin uzun vadeli ve bir süreç olarak ele alınmasıyla birlikte ortaya çıkacağı da göz önünde bulundurulmalıdır.

Insanın hem eğitim hem de günlük hayatında önemli bir yere sahip olan yazma becerisinin öğrencilere kazandırılması sürecinde geçmişten günümüze sıkıntılar yaşandığı, bu konuda her kademedeki öğrenciler başta olmak üzere iş hayatındaki insanların da ciddi eksikliklerinin bulunduğu görülmektedir. Özön (1961: 5), bizde yazma becerisinin geçmişten beri hep zayıf olduğunu, bu çerçevede Şemsettin Sami'nin 1880'li yıllarda, sadece ilkokul mezunlarının değil yüksek okulu bitirenlerin de yazma becerisinden mahrum bulunduklarını ifade ettiğini belirtir. Aynı konuya devamla, 1940'lı yıllarda Falih Rıfkı Atay'ın da yazılarda kullanılan kelimelerin ve dilin zevksiz; anlatışın zayıf olduğundan şikâyet ettiği üzerinde durur. Göğüş (1978) öğrencilerin, kendilerini yazılı olarak ifade etmede genellikle zorlandıklarını; Tekin (1980: 40), yüksek öğretime gelen öğrencilerin yazılı anlatım becerisinin içerdiği davranışlardan ancak \%28'ine sahip olduklarını; Özbay (2000: 102), ortaokul üçüncü sınıf öğrencilerinin yazılı anlatım becerisinin çok zayıf olduğunu, okullarda bu becerinin geliştirilmesine yönelik çalışmalara pek yer verilmediğini belirtmektedir. Daha sonraki yıllarda yapılan çalışmaların sonuçları da yazııı anlatımdaki durumun iyi olmadığını göstermektedir. Üniversite öğrencilerinin yazılı anlatımlarında hem şekil hem de içerik açısından pek çok eksikliğin bulunması (Arıcı, 2008), 8. sınıf öğrencilerinin yazma yeterlilik seviyelerinin $\% 67,7^{\prime} \operatorname{sinin}$ orta, $\% 20,3$ 'ünün düşük düzeyde olması (Canıtezer, 2014); ortaokul öğrencilerinin cümle, paragraf ve metin oluşturma becerilerinin istenen düzeyde olmaması (Bahşi, 2018), söz konusu araştırmalara örnek olarak verilebilir. Görüldüğü gibi geçmişten günümüze yazma becerisinin geliştirilmesiyle ilgili ciddi sıkıntılar mevcuttur. Becerilerin eğitim yoluyla kazandırılıp geliştirilebileceği düşüncesinden hareketle yazma becerisi de hedef kitlenin özelliklerine uygun çalışmalar planlayarak ve bunları uzun vadede uygulayarak öğrencilere kazandırılabilir. Bu kapsamda yazma öğretimi ile yazma eğitimini birbirini tamamlayan unsurlar olarak ele almak gerekmektedir.

Yazma öğretimi, okuma öğretimiyle birlikte örgün eğitimin başladığı ilkokulun birinci sınıfında üzerinde ağırlıklı olarak durulan en temel konulardan biridir. Bu süreçte öğrenciye, öğrenim hayatı boyunca kullanacağı, onun başarısını doğrudan doğruya etkileyecek olan "okuma" ve "yazma" öğretilmektedir. İlkokuma yazma öğretimi kapsamında ele alınan bu becerilerden "yazma" da öğrenciye öncelikle ses-harf ilişkisi kavratılmakta, ardından da harf, hece ve kelimeye uzanan bir süreç içerisinde çocuklara cümle oluşturma ve oluşturulan cümleleri yazma becerisi kazandırılmaya çalışılmakta, bir bakıma becerinin daha çok mekanik yönü üzerinde durulmaktadır. Yani çocuğun gördüğü bir yazıyı veya kendine söylenen bir şeyi yazabilmesi, yazmanın mekanik yönünün öne çıktığı bir yazma etkinliği olarak değerlendirilebilir. 
Eğitim sistemlerinde, okula yeni başlayan çocuklara kalem tutma, kâğıdı kullanma, harfleri tanıma gibi konular yaygın olarak öğretilmekle birlikte ülkemizde, ilkokulun yazı eğitiminin verilişinden sonraki yıllarında yazma eyleminin öğretimi konusunda gereken gelişme sağlanamamıştır (Yalçın, 1998: 146). Bu durumun temel sebebinin "yazma" ile "yazabilme" arasındaki farkın göz önünde bulundurulmaması olduğu söylenebilir. "Yazma" bu becerinin mekanik yönünü; "yazabilme" ise içerik açısından zengin, nitelikli metinler ortaya koyma becerisini karşılar.

Okula başlayan her çocuğun, okuma-yazmanın mekanik ve mantıki yönünü öğretmenlerinin rehberliğinde öğreneceği, ardından da takip edilen Türkçe eğitimi çalışmalarıyla, ele alınan ürünlerdeki hayatı ve olayları anlayıp kavrayacağı söylenebilir. Bu anlama ve kavrama faaliyetiyle birlikte çocuk, yaşadığı hayatı ve olayları önce anlatmaya sonra da yazmaya başlar (Kaya, 1998: 47). Bu aşamada, çocuklara verilecek yazma konularının ve yaptırılacak çalışmaların, onların bu süreçte yaşadıkları ve yaptıkları ile uyumlu olması adına "içinde olay olan ve kendi yaşadıkları/gözlemledikleri türden konular" olmasına özellikle dikkat edilmelidir. Aksi hâlde öğrenciler "yazma"dan soğuyabilir.

Eğitim-öğretim faaliyetlerinin belirlenen amaçlara ulaşması açısından okuma-yazma öğrenimi, ilkokulun birinci sınıfında birkaç aya sığdırılan bir faaliyet olarak düşünülmemeli, bu becerilerin geliştirilmesi ilkokuma yazma mekanizmasının kavratılmasından sonra da devam etmelidir. illkokulun bütün sınıflarında yazma öğretiminin hedefi, öğrencileri işlevsel bir okur-yazar seviyesine ulaştırmaktır. İşlevsel okuma-yazma becerilerinin kazandırıması da bu becerilerin günlük hayatta gerekli görülen yerlerde kullanılabilecek seviyeye getirilmesi anlamını taşımaktadır (Oğuzkan, Öz, Demiray ve Özdemir, 1972: 1). Fonksiyonel okur-yazarlık becerisinin kazandırılması ve kullanılması; sadece ilkokulda değil, ortaokul, lise ve hatta üniversite kademesi için, ardından iş hayatında da düşünülmesi gereken bir konudur.

Yazının yazım ve noktalama yönünün öğretilmesinden sonra ağırlık verilmesi gereken yönün içerik olması gerektiği hep vurgulanır. Yazılı anlatımda içerik açısından zengin yazıların oluşturulması ise kolay değildir. Tekşan (2001: 15) ağır gelişmesi, uzun zaman ve yoğun çaba gerektirmesinden dolayı yazmanın zor bir beceri olduğunu ifade etmektedir. Vygotsky (1998: 144-145) yazı yazmayı "yazılı konuşma" olarak ele almakta ve bunun, sözlü konuşmadan hem yapısı hem de işleyiş tarzı bakımından farklı olan ayrı bir dilsel işlev olduğunu belirtmektedir. Bu kapsamda yazılı konuşmayı; sözlü konuşmanın müzikal, anlatımlı ve sesçil özelliklerinden yoksun, yalnızca düşüncede ve imgelerle yürütülen bir konuşma olarak açıklar. Bu da yazılı dilin soyut bir niteliği olduğunu göstermektedir. Dolayısıyla yazılı anlatım becerisinin geliştirilmesinin uzun zaman aldığı ve zorlu bir süreç olduğu söylenebilir. Maltepe (2006: 58) Türkçe derslerindeki öğrenme-öğretme süreçlerinde gerçekleştirilen yazma uygulamalarının öğrencilerin yazmaya karşı olumsuz tutum geliştirmelerine, bunun sonucu olarak da yazmayı zor bir beceri olarak algılamalarına neden olduğuna dikkat çekmektedir. Yalçın (1998: 148) da yazı yazmanın, kişinin kendini ifade etmesinin ve iletisini/mesajını iletmesinin özel yetenek isteyen çok zor bir iş olduğu yargısının değiştirilemediğini, bu düşüncenin aşılamadığını vurgulamaktadır. Karatay (2011: 22) ise sorunun temelinde "yazma sürecinde dil bilgisi kurallarına sıkı sıkıya bağlı olma ve bunlarla ilgili hata yapma korkusu; duygu ve düşünceleri sıralayamama; bilişsel açıdan düşünme süreçlerinin yeteri kadar gelişmemiş olması veya bunları düzene koyamama" gibi etkenlerin yattığını ifade etmektedir. Görüldüğü gibi "yazma"nın, yapısı ve işleyiş tarzı bakımından farklılığı, sahip olduğu soyut niteliği ve buna ek olarak becerinin eğitimi-öğretimi konusundaki olumsuzluklar bu becerinin geliştirilmesinin önündeki engeller olarak ortaya çıkmaktadır. Yıldız, Okur, Arı ve Yılmaz (2013: 227) yazma çalışmalarındaki temel anlayışın, öğrenciyi öğretmenin bulunduğu seviyeye çekmek değil, onu kendi bulunduğu seviyeden kapasitesi ve algılama-anlama gücüne göre yukarılara doğru çağırmak olması gerektiğini belirtmektedirler. Bu zorlu süreçte yazma becerisinin içerdiği alt boyutları, hem birbirinden bağımsız hem de birbiriyle ilişkilendirerek ele almak, çalışmalardan verim alınmasını sağlayacaktır. Çünkü bir beceriyi alt boyutlarıyla ele almak, parçaya odaklanabilmek, o alt beceride belirli bir düzeye daha rahat çıkabilmek için gereklidir. Süreç temelli yazma eğitiminin her basamağına bu şekilde yaklaşmak ve her basamağın birbiriyle nasıl ilişkilendirileceğini göstermek, bir bütün olarak ele alındığında soyut yönü öne çıkan bir beceriyi somutlaştırmak anlamına da gelir. Bu ise konunun hem anlatılması hem anlaşılması hem de uygulamaların verimli bir şekilde yapılması açısından önemlidir. 


\section{Araştırmanın Yöntemi}

Bu çalışma, betimsel araştırma türlerinden derleme yöntemi ile gerçekleştirilmiştir. Derleme araştırmalarında herhangi bir konuda yayımlanan önemli çalışmaların sınıflandırılması ve değerlendirilmesi yapılır (Hertman, 2006). Özdamar (2003) bir konuda tanımlayıcı bilgiler elde etmek amacıyla yürütülen bu tür çalışmalarda, konunun ayrıntılı bir biçimde tanımlandığını, açıklandığını ve konuyla ilgili belirlemeler yapıldı̆̆ını belirtir. Aydoğdu, Karamustafaoğlu ve Bülbül (2017) de bu araştırmalarda, yapılmış çalışmaların yazarın birikimleri doğrultusunda ilişkilendirildiğini ve bu çalışmalar sonunda ortaya çıkan yayının, incelenen yayın ağının mevcut durumunu ortaya koyduğunu ifade eder. Bu araştırmada genelde yazma eğitimi, yazılı anlatım ve kompozisyon; özelde de süreç temelli yazma alanındaki kitaplar, makaleler, tezler incelenmiş; süreç temelli yazma yaklaşımının "hazırlık" aşamasının alt boyutları ele alınmış, kullanılan yöntem ve teknikler değerlendirilmiştir. Ayrıca Türkçe öğretmenleri için yazma sürecinde söz konusu bilgilerin nasıl kullanılabileceğine dair uygulama örnekleri sunulmuştur.

\section{Süreç Temelli Yazmada "Hazırlık” Basamağı}

Türkçe Sözlük'te süreç “Aralarında birlik olan veya belli bir düzen veya zaman içinde tekrarlanan, ilerleyen, gelişen olay ve hareketler dizisi" olarak tanımlanmaktadır (TDK, 2005: 1830). Bu tanımda "süreç" adı verilen yapının içinde çeşitli unsurların olduğu, bunlar arasındaki ilişkilerin belirli bir düzene göre belirlendiği anlaşımaktadır. Bir anlamda sürecin sağlıklı ilerlemesi ve sonunda verimli bir yapının vücuda gelmesi için söz konusu unsurlar arasında bir sıranın ve düzenin olması gerekir.

Süreç temelli öğrenme-öğretim modeli, sınıf içi öğrenme ve öğretme faaliyetleri için bir çerçeve oluşturur ve öğretmenlerin, öğrencilerine plan ve planlama hakkında bilgi sunmalarını mümkün kılar (Ashman, Wright ve Conway, 1994). Süreç temelli yazma yaklaşımıyla ilgili olarak ülkemizde 2004 yılından itibaren hem doktora hem yüksek lisans hem de makale olmak üzere pek çok çalışmanın yapıldığı, bu çalışmaların ağırlıklı olarak ortaokul ve lisans seviyelerinde yürütüldüğü görülmektedir (Akbaba ve Ayaz, 2017). Bu yaklaşımda; konunun verildiği ve öğrencilerden ürünün istendiği klasik bir yapı yerine, yazma konusu verildikten sonra hangi aşamalardan geçilerek ürünün ortaya çıkacağının öğrencilere uygulamalı olarak gösterildiği bir süreç yaşanır. Duman (2007), öğrenme-öğretme sürecinde öğretimin planlı yürütülmesinin, öğrencinin bilişsel farkındalık stratejilerinin farkına varmasını sağladığını ve bunları kullanmasını geliştirdiğini belirtmektedir. Bilişsel farkındalığı artan öğrencilerin bu kapsamda, çalışmaların niçin ve nasıl yapıldığını anlamaları, kavramaları ve içselleştirmeleri de mümkün olacaktır.

Planlı yazma ve değerlendirme modelinin, bir yönüyle öğretmenin öğrencilerle birlikte yazılı anlatım çalışmalarını planlayıp yürüttüğü bir süreç, diğer yönüyle de öğrencilerin kendi kendilerine yazma becerisini kazandıran yardımcı bir araç olduğunu belirten Karatay (2011: 29) sürecin aşamalarını "hazırlık, yazma taslağı oluşturma, taslağı gözden geçirerek yazma, yazıyı düzeltme, yazıyı paylaşma/yayınlama" olarak ortaya koymaktadır. Bu çalışmada söz konusu aşamalardan "hazırlık"ın önemi açıklanacak, yazma eğitiminde hazırlık aşamasındaki çalışmalar ele alınacaktır.

"Hazırlık" çalışması, geçmişten günümüze bu alanda çalışan hem yerli hem de yabancı araştırmacıların üzerinde önemli durduğu bir konu olmuştur. Gökşen (1964: 353), iyi kompozisyonlar yazdırabilmek için önce öğrencilerin düşüncelerini ve duygularını doğru dürüst ortaya koyabilmelerini sağlamak gerektiğini ifade eder. Rohman (1965: 106) yazma öncesi çalışmalara hak ettiği değerin nadiren verildiğini, yazının başarısı için çok önemli olan bu çalışmaların yazma sürecinde keşif aşaması olarak tanımlandığını belirtir. Bu basamak "yazmadan önce yaz" (Murray, 1978) olarak da ifade edilmektedir. Yazma öncesi hazırık çalışmalarının alanda geniş kabul görmesi "keşfetme ve planlama"nın, yazma sürecinin mantıklı ve gerekli parçaları olarak kabul edilmesini sağlamış, bu da kompozisyon öğretiminin geliştirilmesine yardımcı olmuştur (Flower ve Hayes, 1981: 367). Yazma çalışmalarında harekete geçmenin, bir anlamda hazırlığa başlamanın önemini Clark (2017: 18), fen bilgisi dersi konularından "eylemsizlik"ten hareketle şöyle anlatır: Hareket etmeyen, yani durağan nesneler, dışarıdan bir güç uygulanmadığı sürece durağan kalır; hareket hâlinde olan bir nesne de dışarıdan bir güç tarafından yavaşlatılmadığı veya durdurulmadığı sürece harekete devam eder. Konu, yazma faaliyeti açısından düşünülürse birinci duruma "kötü eylemsizlik" denilebilir ve bu, yazma 
çalışmalarında harekete geçemeyen, durağan yazarları karşılar. "iyi eylemsizlik" denilebilecek diğer durumda ise yazmaya bir defa başlanıldı mı gerisi daha kolay gelebilmektedir. Görüldüğü gibi bir yazma çalışmasında konu üzerinde düşünmeye başlayarak zihni harekete geçirmek "hazırlık"a başlamak anlamına gelmekte ve bu, çalışmayı verimli kılmak açısından büyük önem arz etmektedir.

Hazırlık çalışması sırasında akla gelen her fikrin herhangi bir sınırlamaya tâbi tutulmadan yazılması çok önemlidir. Bazı zamanlarda bir iç ses, akla gelen hususlardan bazılarının "yazılmaya değer olmadığını, kullanılmayacağını, o yüzden de yazılmaması gerektiğini" söyleyebilir. $O$ iç sese kulak asılmamalı, konuyla ilgili olarak zihnimizden açığa çıkan her unsur mutlaka yazılmalıdır. Becker'e (2015: 37) göre bu aşamada tek amaç fikirleri kâğıda dökmektir, bu süreçte hata yapmaktan da korkmamak gerekir; böyle bir korku yazma sırasında ihtiyaç duyulan ipucunun ortaya çıkmasını engeller. Ayrıca yazmanın kurallarına dair aşırı kaygılanmanın gerçekte söylenmek istenenlerin önündeki büyük bir engel olduğu unutulmamalıdır.

Hazırlık çalışmaları kısa ve uzun süreli olmak üzere iki şekilde ele alınabilir. Kısa süreli hazırlık çalışmaları yazmaya başlamadan hemen önce, beş on dakikalık bir sürede gerçekleştirilen; güdüleyici, ilgi çekici ve yönlendirici çalışmalardır. Uzun süreli hazırlık çalışmalarında ise yazmanın dışındaki diğer dil becerileri de işe koşulur ve hem sözlü hem de yazılı anlatım için gerekli olan kültürel birikimin kazandırılmasına yönelik uygulamalar yapılır; bu çalışmalar uzun zaman ister. Öğretmen, kısa süreli ön hazırlık çalışmalarıyla, öğrencilerde yazmaya istek yaratmaya çalışır. Bu da yazma konusunun öğrencinin ilgi ve bilgi alanından seçilmesiyle mümkündür (Tekşan, 2001: 18-20). Bu çalışmada "hazırlık", kısa süreli hazırık olarak ele alınmıştır. Bu kapsamda kısa süreli hazırlık; konu belirleme, konu üzerinde düşünme ve fikir üretme, konuyu sınırlandırma, yazma amacı belirleme, yazı türünü belirleme, hedef kitleyi belirleme (Karatay, 2011; MEB, 2018) alt başlıklarından hareketle incelenmiştir. Özellikle de bu alt başlıklardan ilk ikisi, "hazırıı" basamağının içerik itibarıyla en hacimli olan bölümleridir. Bu yüzden söz konusu başlıkların üzerinde ağırlıklı olarak durulmuştur.

\section{Konu Belirleme}

Çevresiyle sürekli olarak iletişim hâlinde bulunan insan; çeşitli konularla ilgili duygu, düşünce, soru ve tasarılarını diğer insanlarla paylaşma gereği hisseder. Hissedilen bu gereksinimi karşılama sürecinde ele alınan, hakkında yazı yazılan olay, düşünce, duygu ve soruna, yazma dilinde "konu" denir (Özdemir, 1967). Yazma çalışmalarında konu çoğunlukla öğretmenler tarafından belirlenir. Bazı durumlarda da yazma konusunu belirleme konusunda öğrenci serbest bırakılır. Yazma çalışmalarında konu, ister öğretmen ister öğrenci tarafından belirlensin konuyla ilgili olarak göz önünde bulundurulması gereken temel ölçüt şudur: Yazma konusu, öğrencinin seviyesine, bilgi birikimine, yazma kapasitesine uygun olmalıdır. Çünkü yazıı anlatım çalışmalarında hazırlık yapmayı doğrudan doğruya etkileyen en önemli hususlardan biri "konu seçimi"dir. Kendine verilen yazma konusu hakkında hiç bilgisi olmayan veya sınırlı bilgiye sahip öğrencilerden hazırlık çalışması yaparak iyi bir yazı yazmaları beklenemez.

Yazma etkinliklerinde öğrencilere verilecek yazma konuları; onların kendi düşünce, duygu, deney, yaşantı ve bilgilerini anlatma olanağı verecek türden olmalıdır (Göğüş, 1978: 240). Okurer (1967) Batı'daki çalışmalarda yazma sürecinde öğrencilere verilecek yazma konularının, onların kişiliklerine uygun, ilgi ve yeteneklerini üzerinde toplayabilecekleri türden olması gerektiğinin vurgulandığını belirtmektedir. Burdurlu (1984: 11) da sözlü ve yazılı anlatım çalışmalarında öncelikle, yaşanmış konulara yer verilmesi gerektiğini, anlatım becerilerindeki gelişimin ancak bu şekilde gerçekleşebileceğini belirtir ve ardından öğrencilere yazma konusu olarak yalnızca özdeyiş genişletme ödevlerinin verilmesini eleştirir. Ona göre özdeyişlerde savunulması gereken düşünceler vardır, bunun için geniş kültüre ihtiyaç duyulur; geniş kültür de öğrencilerin çoğunda olmadığı için bu çalışmalar genellikle başarısızlıkla sonuçlanır.

Verilecek konunun öğrencinin ilgi ve bilgi alanından olması, öğrencilerde yazma isteği oluşturma açısından da önemlidir (Tekşan, 2001: 20). Çünkü öğrenciler, bilgi sahibi oldukları konularda daha rahat yazarlar. Yılmaz (1998) bazı öğrencilerin, dersin sonuna kadar düşünmelerine rağmen, kendilerine verilen yazma konusuyla ilgili hiçbir şey yazamadıklarına, kendilerine bunun nedeni sorulduğunda da "Aklıma bir şey gelmiyor, ne yazayım?" dediklerine, bu durumun nedeninin de verilen 
yazma konuları olduğuna dikkat çekmektedir. Burada, öğrencilerin zorlandıkları, yazamadıkları konular üzerinde ısrar etmeyip yazma konusunu değiştirmenin önemli olduğunu da belirtmek gerekir. Temizkan (2014: 2) da basmakalıp yazma konularının, yaratıcı fikirlerin ortaya çıkmasını engellediğini, değişik bakış açılarının geliştirilmesinin önüne set çektiğini, bu durumun da öğrencinin birkaç cümleyi değiştirip dönüştürerek sürekli aynı şeyleri anlatmasına, bir kısır döngü içinde kalmasına neden olduğunu vurgulamaktadır.

Öğrencilerin rahat yazacakları ve zorlanacakları konularla ilgili olarak şu hususlara da temas etmekte yarar vardır: Kurudayıoğlu ve Karadağ'ın (2010: 205) çalışmasında öğrenciler, verilen yazma konularından "bizzat yaşadıkları olayları, üzerlerinde etki bırakan yerleri, kendileri için önemli olan insanlarla ilgili konular"ı seçmişlerdir, bu da çocukların hangi konularda daha rahat yazdıklarını göstermektedir. Bununla birlikte yazılı anlatımla ilgili yapılan pek çok çalışmada (Doğan, 2018; Küçük, 2006; Temizkan, 2003; Zorbaz, 2010) Türkçe öğretmenlerinin öğrencilere, yazma çalışmalarında önerilmeyen, "özdeyiş ve atasözü açıklatma”nın konu olarak verildiği görülmektedir. 1940’lı yıllarda liseyi bitiren öğrencilerin üniversiteye gitmek için geçmek zorunda oldukları olgunluk sınavında Türkçe kompozisyon sorusu olarak sorulan "Hayatta en hakiki mürşit ilimdir." özdeyişinin (Başgöz, 2017: 86), 2010'lu yıllarda Türkçe öğretmenleri tarafından 7. sınıf öğrencilerine yazma konusu olarak verilmesi (Doğan, 2018: 957) bu anlamda çarpıcı bir örnektir. Öğrencilerin rahat yazmalarını sağlamak adına onlara tek bir seçenek yerine seçenekler sunmak, hatta sunulan seçenekler üzerinde yazmak istemezlerse kendi belirleyecekleri bir konu hakkında yazabileceklerini belirtmek; yazma çalışmalarında "konu"dan kaynaklı tıkanma, yazamama durumlarını ortadan kaldıracak bir yaklaşım olarak değerlendirilmelidir.

"Konu" başlığı üzerinde dururken, "konunun özelleştirilmesi"ni de ele almak gerekir. Yazma konusu eğer genel bir nitelikteyse konunun özelleştirilmesi yazının daha kolay yazılması açısından önemli olabilir. Genel konular üzerinde derinleşmek, o konuyu çeşitli açılardan ele almak zordur. Bu durum, yazılı anlatım konusunda çok tecrübeli olmayan öğrenciler açısından farklı bir zorluk olarak değerlendirilebilir. O yüzden öğrencilere verilecek yazma konularının "genel"den ziyade "özelleştirilmiş" olması, öğrencilerin daha rahat hazırlık yapmaları ve yazı yazmaları açısından önemlidir. Karaalioğlu (Tarihsiz: 137) özelleştirme de denilebilecek sınırlandırmanın kafayı bulanıklıktan kurtardığını; yazıyı eksiklik ve fazlalıktan arındırdığını belirtir. Bundan dolayı yazma çalışmalarında öğrencilere genelden ziyade özelleştirilmiş konular vermek ve aynı zamanda genel konuların nasıl özelleştirilebileceğine yönelik örnekler sunmak, bunun mantığını kavratmak yararlı olacaktır. Genel ve özelleştirilmiş konulara şunlar örnek olarak verilebilir:

gezi - okul gezisi (bir basamaklı özelleştirme)

alışveriş - semt pazarında alışveriş (bir basamaklı özelleştirme)

sevgi - insan sevgisi - anne sevgisi (iki basamaklı özelleştirme)

yiyecekler - meyveler - yaz meyveleri (iki basamaklı özelleştirme)

Örneklerdeki "okul gezisi, semt pazarında alışveriş, anne sevgisi, yaz meyveleri" konuları, özelleştirilmiş konu başlıkları olduğu için bunlarla ilgili hazırlık yapmak ve yazı yazmak, "gezi, alışveriş, sevgi, yiyecekler" konularıyla ilgili yazı yazmaktan daha kolaydır. Yukarıda da belirtildiği gibi "özel" konularda konunun sınırları daha belirgindir; bilgiler, düşünceler bir nokta üzerinde ve çevresinde ortaya koyulur. Bu da anlatımda dağınıklığı önler. Dolayısıyla yazma çalışmalarında konu ve konunun özelleştirilmesi oldukça önemlidir.

Yazma eğitimi çalışmalarında öğrencilere "konu"nun verilmesinden sonra işlemeye başlayan süreçte, zihnin harekete geçmesi olarak da adlandırılabilecek "düşünme" başlar. Ele alınacak yazma konusuyla ilgili zihinde var olan bilgilerin, konunun bize düşündürdüklerinin, hissettirdiklerinin açığa çıkarılmasında "düşünme" önemli bir eylem olarak ele alınmalıdır. Düşünme sonucu ortaya çıkan bilgi ve düşüncelerin ne kadarının ne şekilde kullanılacağına ise bunların sınırlandırılması yani bunlar içinden yapılacak seçme ile karar verilir.

\section{Konu Üzerinde Düşünme ve Fikir Üretme}

Düşünme, hazırlık aşaması başta olmak üzere yazma çalışmalarının tamamında kullanılan bir araçtır. Yazma konusunun ele alınmasına ve ortaya çıkan verilerin ne şekilde kullanılacağına "düşünme" 
işi yardım eder. Guitton (1968: 38), düşüncenin bir takdir ve muhakeme gücü sayıldığını, insanı da diğer canlılardan ayıran niteliğin bu olduğunu belirtir. Ayrıca, insanın dış âlemdeki eşyanın hükmü altına girmediğini, duyguları vasıtasıyla gelen her şeye hâkim olduğunu, onları mukayese ve muhakeme ettiğini; düşünmenin eğri ile doğruyu ayırt etmek, ifratla tefritten kaçmak, tam ve sağlam olanı bulmak anlamına geldiğini ifade eder. Aslında yazma eğitimi çalışmalarının bütün aşamalarında düşünme yoluyla yapılan işlerin "takdir, mukayese ve muhakeme etme" olduğu belirtilebilir. Bu açıdan bakıldığında yazmayı öğretmek ile düşünmeyi öğretmek çok sıkı bir ilişki içindedir. Bu husus, yazmayla ilgili alanyazında da üzerinde durulan önemli konulardan biridir.

Özdemir (1967: 7), yazma işinin açık ve aydınlık düşünmeyle, söyleneceklerin zihinde tam belirmesiyle başlayan bir süreç olduğunu belirtir. Kantemir (1972: 142) düşüncenin ilk işinin "kelimelerle ifade edilen ve birbirine karışmış halde olan anlamları ayırmak, onları ayrı ayrı kullanmak ve birbirine karşı koymak için, ayrı adlar vermek" olduğunu ifade eder. Emir'e (1986: 56) göre iyi ifade etmenin temelinde iyi düşünmek vardır; düşünme eylemi sonucunda ortaya çıkan düşünceler yeni düşünceler doğurur, bir düşünceden elde edilen yargı bir başka düşüncenin temeli olabilir. Raimes'e (1980: 799) göre de fikirlerin oluştuğu ve yeniden düzenlendiği bir süreç olan yazma, "düşünme"den ayrılamaz. Bu yolla dili kullanmadaki becerilerini; fikirleri keşfetmek, sentezlemek ve iletişim kurmak için kullanan öğrenciler konuyu daha iyi öğrenirler. Ona göre yazmak, okuldaki derslerde her zaman yapılan bir iş hâline geldiğinde de düşünme ve öğrenme, dolaylı olarak da yazmanın kendisi gelişecektir. Yalçın (2018: 363) ise yazma becerisi ile düşünme becerisi arasında doğrudan bir bağlantı olduğunu, bu kapsamda amacı ne olursa olsun bir yazı yazılması sırasında "düşünme, üretme ve planlama"nın önemli aşamalar zinciri olarak karşımıza çıktığını, yazııı metni oluşturmanın bunlardan sonra geldiğini belirtmektedir. Bu görüş ve düşüncelerden hareketle yazma sürecindeki hazırlık aşamasında "düşünme, açığa çıkan bilgi ve düşünceleri not etme"nin önemini vurgulamak gerekir.

Hazırlık basamağında, ele alınan konu üzerinde düşünmek, beyin fırtınası olarak da adlandırılabilir. Özellikle sınıf içinde örnek olarak yapılan hazırlık çalışmalarında, yazma konusuyla ilgili ifade edilen görüşler ve bunların düzenlenmesi bu kapsamda değerlendirilebilir. Beyin fırtınası sonucunda ortaya çıkan fikirlerin birbiriyle ilişkilendirilerek kümelenmesi bu aşamada bir sonraki adım olarak karşımıza çıkar. Tansel (1963) düşünceleri ortaya koyarken tam cümleler değil, kelime ve ibareler kullanılması gerektiğini belirtir. Türkçeye "kümeleme" diye çevirebileceğimiz "cluster" yönteminde de hazırlık sırasında konuyla ilgili olarak akla gelen unsurlar kelime veya ifadeler şeklinde yazılır (Durukafa, 1992). Gökşen (1964: 353) ise tabiî planla ilgili görüşlerini ifade ederken verdiği hazırlık örneğinde, yazı yazılacak konuyla ilgili akla gelenleri cümleler hâlinde ortaya koymuştur. Aslında burada önemli olan husus, hazırlık çalışması yapılırken akla gelen fikirlerin, bilgilerin; ister kelime, ister ifade, ister cümle olsun bir şekilde yazılmasıdır. Hatta aynı hazırlık çalışması içinde her üç yapı da kullanılabilir. Nitekim Warriner (2004: 361) da hazırlık çalışmasında beyin fırtınası yapıldığı zaman konuyla ilgili akla gelen düşünce, kelime veya ifadenin yazılması gerektiğini belirtir. Burada üzerinde önemle durulması gereken asıl husus hazırlık çalışması yapmak ve bu düşünme faaliyeti sırasında konuyla ilgili akla gelenleri herhangi bir kısıtlamaya tâbi tutmadan not etmektir.

Hazırlık çalışması sırasında kullanılan kümeleme, öğrencilere yazmanın yanında başka katkılar da sağlar. Henry'ye (1986) göre kişinin belli bir konu hakkındaki bilgilerini kendi kelimeleriyle yazması; bunları sorgulaması, değerlendirmesi, bütünleştirmesi önemli bir öğrenme yoludur ve bu kapsamda kümeleme, ekonomi gibi farklı alanlardaki yazma çalışmalarında da kullanılabilmektedir. Zaten kümeleme yöntemini kullanarak yazmak, herhangi bir alana özgü olmayıp konunun ele alınış ve bilgilerin ortaya konuluş biçimine odaklanmak anlamına gelmektedir.

Kasapoğlu (2007: 50) Türkiye ve Almanya'daki ilkokul dördüncü sınıf ana dili ders kitaplarında yazma eğitimi ve öğretimini karşılaştırdığı çalışmasında "yönlendirilmiş yazma çalışmaları"ndan bahsetmektedir. Bu çalışmaların; sorulan soruları cevaplandırarak bir metin oluşturma, beyin fırtınası veya çağrışım tekniklerini kullanarak konu hakkında duyguları harekete geçirme, düşünceleri toplama ve bunları bilgi ve tecrübeye dayanarak sınıflandırma, karşılaştırma yapma şeklinde yürütülebileceğini belirtmektedir. Görüldüğü gibi bu çalışmada beyin fırtınasının, çağrışım tekniklerinin kullanııması, bilgi ve birikimin açığa çıkartılması ve bunların sınıflandırılması gibi işlemler süreç temelli yazma çalışmasının "hazırlık" basamağındaki çalışmalarla büyük benzerlik göstermektedir. Kasapoğlu (2007: 226), 4. sınıf 
Almanca ders kitaplarında Türkçe ders kitaplarına göre üç kat daha fazla yönlendirilmiş yazma etkinliğine yer verildiğini tespit etmiştir. Bu sonuç, Türk öğrencilerin ders kitaplarında, yazma becerisini geliştiren türden çalışmalarla Alman öğrencilere göre çok daha az karşılaştıklarını göstermektedir. Yazma becerisinin geliştirilmesinde, beceriyi oluşturan alt boyutlar üzerinde çalışmanın önemi ve gerekliliği göz önünde bulundurulduğunda söz konusu durumun Türk öğrencilerin yazma becerilerini olumsuz etkilediği söylenebilir. Bu durum da yazma eğitiminde süreç temelli yazma yaklaşımının esas alınmasını gerekli kılmaktadır.

Süreç temelli yazma yaklaşımının başlangıç basamağı olan hazırlıktaki düşünme faaliyetlerinden, yazma çalışmalarında çeşitli şekillerde yararlanılabilir. Göğüş'e (1978: 244) göre yazma çalışmalarında öğretmen, öğrencisinin düşünmesine yardım etmelidir. Bu kapsamda öğretmen, iyi yazabilmesi için öğrencinin düşüncesini durulaştırmalı; doğruyu ve gerçeği seçmesine, bir sonuca ulaşmasına yardım etmelidir. Öğretmen bunları; öğrencisini, yazacağı konu üzerinde konuşturarak, ona sorular sorarak yapabilir. Böyle bir uygulama, hem öğretmenin hem de öğrencinin aktif olduğu ama düşünce üretme konusunda öğrencinin daha fazla rol aldığı bir yapı olarak karşımıza çıkar. Bu uygulamada öğrenciler, kendilerinden bekleneni ortaya koyma konusunda zayıf kalırlarsa öğretmen, süreci yönetmek ve öğrencilere nasıl düşüneceklerini göstermek adına "sesli düşünme yöntemi"ni de kullanabilir.

Kökleri psikolojik araştırmalara dayanan sesli düşünme yöntemi, iç gözlem yönteminden hareketle geliştirilmiş olup zihinde gerçekleşen olayların az veya çok, dış dünyada gözlemlenebileceği fikrine dayanır (Van Someren, Barnard ve Sandberg, 1994: 29). Süreç temelli öğrenme modelinde öğretmenler, düşünceleri planlama aşamasında sesli düşünerek öğrencilerine rehberlik ederler ve onlara nasıl öğrendikleriyle ilgili bilişsel farkındalık kazandırmayı amaçlarlar (Ashman, Wright ve Conway, 1994: 202). Eş zamanlı sesli düşünme, yazarların bilişsel süreçleri hakkında önemli bir bilgi kaynağı oluşturmaktadır. Yazma araştırmalarında sesli düşünmenin kullanılmaya başlanmasıyla zihinsel bir eylem olarak yazma anlayışında değişiklikler meydana gelmiştir (Janssen, Van Waes ve Van den Bergh, 1996). Öğretmenler, hazırlık aşamasında sesli düşünme yöntemini kullanırken, öğrencilerden sadece gözlem yapmalarını, kendi söyledikleriyle ilgili yorum yapmamalarını isteyebilir. Böylelikle öğretmenin, dış müdahalelere maruz kalmadığı bir sesli düşünme sürecini daha doğal bir şekilde öğrencilere sunma imkânı olur. Sesli düşünme sürecinde öğretmen "kendi kendine sorular sorup bunların cevaplarını alma, yazma konusuyla ilgili olarak aklına gelenleri nasıl not alabileceğine dair yorumlar yapma, zaman zaman aklına gelen düşüncelerden bazıları yazmama, hemen ardından bu davranışını eleştirerek yazmadığı düşüncelerini not alma, not aldığı ifadelerden bazılarını süreç içerisinde güncelleme" gibi davranışlarla, bir hazırlık sürecindeki düşünme ve fikir üretmede herkesin yaşayabileği durumları örneklendirmelidir. Bu düşünce ve davranışlar, bağımsız olarak hazırlık çalışması yapma konusunda öğrencilere cesaret veren, nasıl düşünebilecekleri konusunda onların zihinlerinde kulvarlar açan uygulamalardır.

Yazı yazmak; gelişigüzel dizilmiş cümleler, üst üste yığılmış kelimeler topluluğu değil; düşünceleri, duygu ve istekleri mantıklı ve disiplinli bir şekilde anlatmaktır (Emir, 1986: 53). Yazmak bir anlamda, düzen demektir. Bu düzeni sağlayabilmek için yazma konusu üzerinde düşünmek, elde edilen malzemeleri kendi içinde değerlendirmek, yazılı anlatım için gerekli olan planın altyapısını hazırlamak anlamına gelir. Bu konuda Buffon, konu üzerinde yeter derecede düşünülmediği zaman kişinin yazma sırasında bocalayacağını, yazıya nereden başlayacağını bilemeyeceğini belirtir; kişinin zihnine birçok düşüncenin birden dolacağını, onları değerlerine göre sıraya koymadığı için birini ötekine tercih edemeyeceğini, kararsızlık ve şaşkınlık içinde kalacağını ifade eder. Düşünme yoluyla planın altyapısı hazırlandığı zaman ise fikirlerin daha rahat toplanıp bir düzene koyulacağını, sonrasında da yazmanın bir zevk hâline geleceğini vurgular (Akt. Gözler, 1974: 141). Tansel (1963) de birçok fikrin zihnimizde bir arada, mantığa uygun bir şekilde oluşması ve gelişmesinin zor olduğunu, etkili bir anlatım için, tanınmış yazarların bile plan yaptıklarını, fikirlerin başıboş bir şekilde hareketini önlemek için bir plana dâhil edildiğini belirtir. Asiltürk (2017: 15) ise çok düzgün ve iyi ifadeler de kullanılsa, plansız bir yazının başarılı olamayacağını vurgular. Burada üzerinde durulan plan bir anlamda, düşünce olarak zihinde var olan unsurların kâğıda yazılması, o düşüncelerin somutlaştırılması ve böylelikle o unsurların daha iyi kullanılmasını ifade etmektedir. Kişi, hazırlık çalışması kapsamında yazdığı notları, daha rahat 
incelemekte; bu notlardan hangilerini, nasıl kullanacağına; hangilerini kullanmayacağına dair kararını daha rahat verebilmektedir. Bu ise yazma işini kolaylaştırmakta, "yazmanın zor olduğu"na dair önyargının ortadan kalkmasına yardımcı olmaktadır.

Yazma çalışmalarının başında düşünme yoluyla planın altyapısının oluşturulması; konunun sınırlarının çizilmesine, tesadüflerin neden olduğu hazırlıksız bocalamaların önlenmesine, yazı yazan kişiyi yerinde saymaktan kurtararak konuya yön verilmesine; duygu, düşünce, dilek ve görüşlerin düzenlenerek sıraya konulmasına yardımcı olur. Bununla birlikte bir yazı için yapılan plan, oynaklık ve manevra alanı isteyebilir. Böylelikle plandaki fikir ve bilgi boşlukları örtülür (Ertan, 1942: 30). Görüldüğü gibi düşünme yoluyla oluşturulan plan altyapısı, yazma sürecini çok farklı açılardan etkileyen ve düzenleyen bir iştir. Bununla birlikte hazırlık çalışması aşamasında ortaya konulan plan altyapısının tüm yönleriyle bir kesinliğinin olmadığı, plan yapıldıktan sonra veya süreç temelli yazma yaklaşımının ilerleyen aşamalarında plan altyapısına göre başlanan yazma sürecinde, başta oluşturulan yapıda bazı düzenlemelere gidilebileceği bilinmelidir. Bu ise dinamik bir yapıya sahip olan yazma sürecinde doğal kabul edilmesi gereken bir durumdur.

Gökşen'e (1964) göre bir konuyla ilgili yazı yazarken çeşitli etmenlerin etkisi altında kalırız ve yazdığımız yazı; okuduklarımızın, dinlediklerimizin, gördüklerimizin, düşündüklerimizin ve hissettiklerimizin ortak ürünüdür. Bu çerçevede öğrencilerin değerli yazılar yazabilmeleri için duygu ve düşüncelerini doğru dürüst ortaya koyabilmeleri gerekir. Bunun için de onların zihninde her şeyden önce plan düşüncesi, plan anlayışı yer etmelidir diyen Gökşen (1964), "tabiî plan" dan bahseder. Aslında onun "tabiî plan" dediği şey, bir yönüyle hazırlık aşamasındaki "düşünme ve fikir üretme"yi karşılar. Yazar, bu aşamada yapılan işi, yayığa konulan sütten yağ çıkarmaya benzetir. Aslında tereyağ hem sütten elde edilen kremadan hem de sütün mayalanmasıyla yapılan yoğurttan üretilebilir (MEB, 2013: 5). İster süt kreması olsun ister yoğurt, tereyağ yapım aşamasında benzer süreçler işe koşulur. Bu süreci Gökşen (1964: 353) “...süt, yayıkta dövüldükçe sütün içinde bulunan yağ parçacıkları ayrılmağa, belirli bir durum almağa başlarlar. Devamlı karıştırma ve basınç sonunda sütün içindeki bütün yağlar meydana çıkmış olur." şeklinde anlatır. Devamında da bu örneği yazı yazma süreciyle ilişkilendirerek yazı yazmak isteyen kişinin, bir yazma konusu ile karşılaştı̆̆ında zihninde -tıpkı sütün içindeki yağ taneciklerinin ortaya çıkarılması gibi- o konuya ilişkin birtakım düşüncelerin belirdiğini, zihinde ya da bilinçaltında yerleşmiş izlenimlerden yazma konusuyla ilgili olanlarının yavaş yavaş belirli bir durum almaya başladığını, zihinde bir ayıklama ve toplaşmanın olduğunu, o konu dışındakiler uzakta kalırken, konuyla ilgili olan unsurların meydana çıktığını belirtir. Sonrasında yapılacak işin, zihinde toplanan bu konu parçacıklarını rastgele, kısa kısa, alt alta yazıvermek olduğunu ifade eder. Burada "yazıvermek" kelimesi üzerinde kısaca durmakta yarar vardır. Tezlik anlamı barındıran bu kelime, hazırlık aşamasında konu üzerinde düşünürken akla gelen hususların herhangi bir engellemeye tâbi tutulmadan not edilmesinin önemini vurgulamaktadır. Düşünme aşamasında açığa çıkan unsurlardan hangilerinin, yazma sırasında kullanılıp hangilerinin kullanılmayacağına dair tespit "hazırık"ta yapılmamalıdır. Nitekim hazırlık yaparken, yazma sürecinde kesin kullanılacağı düşünülen bir unsurun metni oluştururken kullanılmadığı, büyük ihtimalle kullanılmaz denilen bir bilginin veya düşüncenin ise kullanıldığı durumlarla karşılaşılabilmektedir. $O$ yüzden düşünme ve fikir üretme aşamasında ortaya çıkan unsurların hepsinin not edilmesi, bunlardan hangilerinin kullanılacağına dair verilecek kararın sonraya bırakılması, zihindeki malzemenin verimli kullanılması açısından önemlidir.

Yazma sürecindeki çalışmaları somutlaştırmak adına yukarıda ele alınan tereyağ yapımı ile bir yazının yazııması sürecindeki aşamalar şu şekilde eşleştirilebilir:

Tablo 1.

Tereyağ Yapma ile Yazı Yazma Aşamalarının Eşleştirilmesi

Tereyağ Yapımı

Temel şart: Sütün/yoğurdun yağlı olması
Bir Yazının Yazılması

Temel şart: Yazma konusunun seviyeye uygun olması 
İçinde süt/yoğurt olan yayığın çalıştırılması (Yağ parçacıklarının daha kolay bir araya gelmesi için yayığa soğuk su/buz konulabilir.)

Sütün/yoğurdun içindeki yağ parçacıklarının ayrılıp bir araya gelmeye başlaması

Yayığın durdurularak yüzeye çıkan yağ parçacıklarının bir kaba alınması

Yayığın tekrar çalıştırılması

Yayığın durdurularak yüzeyde yeni toplanan yağ parçacıklarının alınması

Bir önceki basamağın birkaç kez tekrarlanması

Yayığın çalıştırılmaya devam edilmesine rağmen yüzeyde yağ parçacı̆ı̆ının oluşmaması

Bir kapta toplanan yağ parçacıklarının soğuk su ile yıkanarak süt/ayran kalıntılarından arındırılması

Yağ parçacıklarının yoğrularak soğuk su ile yıkanması ve süt/ayran kalıntılarından arındırılması

Tereyağın kullanıma hazır hâle getirilmesi
Yazma konusu üzerinde düşünülmeye

başlanması (Zihindeki bilgilerin daha rahat açığa çıkması için ortam; rahatık, sessizlik, sıcaklık, dikkati dağıtan unsurların kaldırılması vb. açılardan uygun hâle getirilebilir.)

Yazma konusuyla ilgili zihinde var olan bilgilerin açığı çıkmaya başlaması

Düşünmeye ara vererek yazma konusuyla ilgili açığa çıkan bilgilerin kısa kısa not edilmesi

Düşünmeye devam edilmesi

Yazma konusuyla ilgili açığa çıkan, konunun diğer yönleriyle ilgili bilgilerin not edilmesi

Bir önceki basamağın birkaç kez tekrarlanması

Düşünülmeye devam edilmesine rağmen not alınanların dışında başka bir düşüncenin açığa çıkmaması

Kâğıda not alınan hususların gözden geçirilmesi, kullanılacak ve kullanılmayacak unsurların belirlenmesi

Kullanılacak unsurların birbiriyle ilişkilendirilmesi ve bir sıraya dizilmesi

Sıraya dizilen unsurları kullanarak yazının yazılması ve paylaşılması

Tablo 1'de görüldüğü gibi tereyağ yapımı ile bir yazının yazılması aşamaları büyük oranda birbirine benzemektedir. Yukarıdaki eşleştirmede, bütünlüğü bozmamak adına, tereyağ yapımı ile süreç temelli yazma yaklaşımının bütün basamaklarına yer verilmiştir. Sadece hazırlık aşaması düşünüldüğünde, tabloda son üç basamağa kadar olan bölümlerin ele alınabileceği belirtilmelidir. Diğer bir ifadeyle tabloda "Yayığın çalıştırılmaya devam edilmesine rağmen yüzeyde yağ parçacığının oluşmaması" basamağı dâhil olan bölüm "hazırlık" içinde değerlendirilebilir.

"Konu üzerinde düşünme ve fikir üretme" ile ilgili yapılan açıklamaların ardından iki örnek üzerinde durulacaktır. Bu örneklerden birinde, ele alınan yazma konusuyla ilgili olarak ortaya çıkan bilgi ve düşünceler cümleler hâlinde ortaya koyulmuştur; bir anlamda listelenmiştir. Diğerinde ise kümeleme yönteminin kullanıldığı; yazma konusu hakkında bilinenlerin kelime ve ifadeler kullanılarak merkezdeki konunun çevresine yazıldığı bir örnek paylaşılmıştır.

\section{1. Örnek}

Yazma konusu olarak "Kış Hazırlığı" verilmiş olsun. Bu konu üzerinde düşünülmeye başlandığında akla gelen hususlar cümleler hâlinde şu şekilde yazılabilir:

- Kışın rahat etmek için kış gelmeden önce hazırlık yapmak önemlidir.

- Kış hazırlıklarından bazıları yazın, bazıları sonbaharda yapılır.

- Yapılan kış hazırlıkları bölgeden bölgeye değişiklik gösterebilir.

- Kış hazırlığı yapmak özellikle kimler açısından önemlidir?

- Her insan kış hazırlığı yapar mı?/Kış hazırlığı yapmayan insanlar var mıdır?

- Kış hazırlığı olarak neler yapılır? 
- Kış hazırlıklarından bazıları beslenmeyle, bazıları barınmayla ilgilidir.

- Hazırlık nedir ve hangi durumlarda hazırlık yapılır?

- Kıyafetlerle ilgili kış hazırlığı da yapılır.

- Hazırlık yapılmazsa kışın zor durumda kalınabilir.

Yazıya hazırlık için yukarıdaki cümleler akla geldiği sırayla yazılmış olsun. Konuyla ilgili olarak zihne artık herhangi bir şey gelmediğinde düşünmeye son verilmeli ve yazılan maddeler gözden geçirilmelidir. Gözden geçirme sırasında birbiriyle ilişkilendirilebilecek maddeler işaretlenmeli, kullanılmayacak maddeler belirlenmelidir. Bu çalışma, düşünme faaliyetinin son aşamaları ve "hazırık"ın bir sonraki boyutu olan konuyu sınırlandırmaya geçişin ilk adımları olarak da kabul edilebilir.

Görüldüğü gibi yukarıdaki cümlelerden bazıları soru cümlesi, bazıları düşünce cümlesi, bazıları da bir durumu anlatan cümledir. Yazma sırasında her bir cümlenin kendi içinde farklı şekilde detaylandırılabileceğine dair notlar da ilgili cümlelerin yanına yazılabilir. Bu tür hazırlıklarla ilgili ilk örneklerde öğretmenin, yapacağı uygulamalarla öğrencilere model olmasında yarar vardır. Yapılacak uygulamalarda sesli düşünme yöntemi kullanılabilir.

\section{2. Örnek}

Hazırlık aşamasında konu üzerinde düşünme ve fikir üretmeyle ilgili ikinci örnek, Türkçeye "kümeleme" diye çevrilebilecek "cluster" yöntemi kullanılarak yapılacaktır. Durukafa (1992) bu yöntemde beynin her iki yarısının da aktif olarak kullanıldığını, yapılan beyin fırtınası sırasında akla gelen unsurların önüne set çekilmemesi ve merkeze yazılan çekirdek kavramla ilgili akla gelecek her unsurun merkezdeki unsurun çevresine yazılması gerektiğini belirtir. Bu bir anlamda imgeleri kendi akışına bırakmak anlamına gelmektedir.

İkinci örnekteki yazma konusu "Sağlıklı Beslenme" olsun.

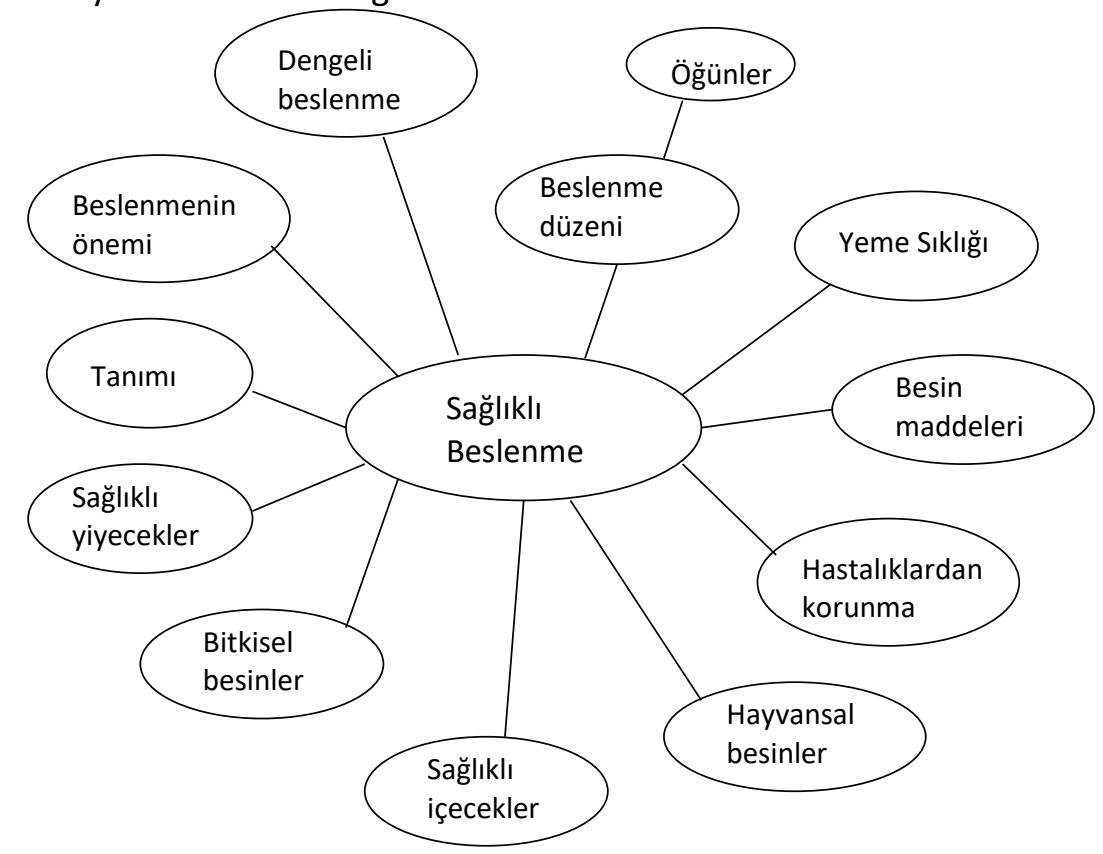

Merkeze yazılan konu üzerinde düşünülmeye başlanır ve konuyla ilgili olarak akla gelen hususlar kelime veya ifade olarak merkezdeki konunun çevresine yazılır, yuvarlak içine alınır ve bir çizgi ile merkezdeki konuya bağlanır. Burada, rahat algılanması için yazılanların yuvarlak içine alınması önemlidir. Konuyla ilgili olarak akla gelen boyutların yeterli olduğu fikri oluştuğunda düşünme bırakılır ve yazılan maddeler gözden geçirilir. Birbiriyle ilişkilendirilebilecek maddeler olup olmadığına karar verilir. Ele alınmayacak madde veya maddeler varsa onlar belirlenir. Bu işlem de "düşünme"nin son aşamaları olarak değerlendirilebilir.

Yukarıda ele alınan örnekler incelendiğinde aslında her iki çalışmanın da farklı yönleri olduğu gibi ortak yönlerinin de bulunduğu görülür. Illk örnekte, yazma konusuyla ilgili akla gelenler cümleler şeklinde yazılmışken ikinci örnekte kelime veya ifade şeklinde not edilmiştir. Illk çalışmada cümleler alt alta yazılırken ikincisinde kelime ve ifadeler merkezdeki konunun etrafına yazılmış ve yuvarlak içine 
alınmıştır. Dolayısıyla ikinci örnekte görselliğin daha ön planda olduğu söylenebilir. İster cümle ister kelime veya ifade şeklinde yazılsın, yazma konusuyla ilgili yapılan bu hazırlık, yazmaya başlamadan önce konuyla ilgili detaylı bir düşünme sürecinin yaşanmasını sağlar. Ortaya çıkan malzemenin nasıl kullanılacağının ele alınması ikinci bir düşünce sürecinin işe koşulması anlamına gelir. Bu iki düşünme sürecinin ardından kişi daha rahat yazmaya başlayacaktır. Dolayısıyla hazırlığın bir boyutu olan "konu üzerinde düşünme ve fikir üretme" çalışmaları, yazmanın temelini oluşturan çok önemli bir süreç olarak ele alınmalı, yazılı anlatım becerisini geliştirmede inmal edilmemelidir.

\section{Konuyu Sınırlandırma ve Yazma Amacını Belirleme}

Konu üzerinde düşünerek, öğrencileri düşündürerek fikirler üretip konuyla ilgili onların bildiklerini ortaya koyduktan sonra hazırlık aşamasında sıra; konunun sınırlandırılmasına ve yazma amacını belirlemeye gelir. Buradaki sınırlandırma, bir önceki aşamada ortaya koyulan bilgi ve düşüncelerden hangilerinin yazılacak yazıda kullanılmasına karar vermek anlamına gelmektedir. Zaten bu işin temelinin bir önceki boyutta atılmaya başlandığı da söylenebilir. Karatay’a (2011: 32) göre konunun sınırlandırıması, ortaya konulan yapıların zenginleştirilmesini, daha kolay kontrol edilmesini sağlar; konu daraldıkça düşünceler, daha fazla odaklanıldığı için derinleşir ve ayrıntılar ortaya çıkar. Bunun ardından da yazma amacı ve bu amacı desteklemek için nelerin, nasıl yazılacağı belirlenir. Yazma amacını belirleme, sonraki aşamalardan yazının türünü belirlemede de etkilidir. Bir anlamda yazma amacını belirlemek yazının türü için de yazıyı yazacak kişiye seçenekler sunar.

\section{Yazı Türünü ve Hedef Kitleyi Belirleme}

Metin üreticisinin niyeti, amacı; metnin türünü belirleyen bir unsur olarak ortaya çıkmaktadır (Sarar Kuzu ve Soytürk, 2019: 16). Yukarıda da belirtildiği gibi yazma amacı belirlendiği zaman "hazırlık"ın önceki aşamalarında ortaya koyulan düşünceler ve bilgilerden hangilerinin nasıl kullanılabileceği de belirli bir hâl almaya başlar. Lyons (1977), metnin iletişimsel amaçlara hizmet ettiğini, bu amaçların da bilgilendirici, anlatımsal ve toplumsal olmak üzere üç kümede sınıflandırılan dilin kullanımsal amaçlarıyla doğrudan ilişkili olduğunu belirtir. Bu kapsamda bilgilendirici amaçlar, bilgilendirici metinler aracılığıyla bilgi vermeyi; anlatımsal amaçlar, estetik metinler aracılığıyla bireyi farklı kılan içsel özelliklerin aktarımını, toplumsal amaçlar ise insan ilişkilerini düzenlemeyi içerir (Akt. Sarar Kuzu ve Soytürk, 2019). Türkçe Dersi Öğretim Programı'nda (MEB, 2019) ise yazma becerisiyle ilgili kazanımlar incelendiğinde şiirin dışında "bilgilendirici metin yazma" ile "hikâye edici metin yazma"nın öne çıkarıldığı görülmektedir. Bu kapsamda, yazma amacının okuyucuyu bilgilendirmek olduğu bir durumda yazı türü deneme, makale, gezi yazısı gibi türlerden biri olabilir. O zaman yazıda öne çıkacak husus, düşünme ve fikir üretme aşamasında ortaya koyulan unsurları, okuyucuyu bilgilendirecek şekilde kullanmak olacaktır. Kişinin başından geçen veya gözlemlediği bir olayı okuyucuyla paylaşmak istediği durumda ise hikâye, anı vb. türleri kullanacağı hikâye edici metinler ortaya çıkacaktır.

Yazma eğitiminde öğrencilerin rahat ve kolay yazmalarının önemi göz önünde bulundurulduğunda çalışmaların olay yazıları ağılıklı olarak yürütülmesinde de yarar vardır. Bu konuda Burdurlu (1984) ilkokul, ortaokul, lise olsun her eğitim basamağında yaşanmış konulara ve bunları içeren türlere önem verilmesi gerektiğini; hem konuşma hem de yazmada gelişimin, kolaydan başlayan çalışmalarla gerçekleşebileceğini belirtir. Bu kapsamda "anılar, günlükler, öz yaşam öyküleri" gibi yaşanmış zamandan örneklerden başlanılabileceğini, ardından "anıları öyküleştirmek, yaşanmış olayları kısa oyun biçiminde yazmak" gibi yaşanmış olaylardan yararlanarak öteki türlere atlayan örneklere geçilebileceğini ifade eder. Bunların ardından da atasözü, özdeyiş genişletme; inceleme ve eleştirme; fıkra, söyleşi, makale, deneme yazma çalışmaları yaptırılmasının kolaydan zora doğru bir süreci hayata geçirmek anlamına geldiğini vurgular. Burada özellikle vurgulanması gereken husus şudur: Yazma amacına göre yazının türüne karar verilse de öğrencilerin rahat yazabilmelerini ve yazı yazmayı sevmelerini sağlamak da en önemli yazma amaçlarından biri olarak ele alınmalıdır. Bu kapsamda yazma amacı ve yazı türünü belirlemede bu husus da göz önünde bulundurulmalıdır.

Yazı türünün belirlenmesinin ardından hedef kitleyi tespit etmek, eldeki malzemeyi kullanırken yazıyı yazacak kişiye yol gösterir. Öğrenciler, oluşturacakları yazıyı akranlarına, yetişkinlere veya genel 
olarak herkese hitap edecek şekilde ele alabilirler. Eğer yazılacak yazının hedef kitlesi kendi akranları ise bu, yazma konusunun ve kullanılacak örneklerin onların ilgisini çekecek şekilde ele alınmasını gerekli kılar. Hedef kitle "herkes" olacağı zaman ise anlatımın ona göre ayarlanması, özellikle yazıda verilecek örneklerin genele hitap edecek şekilde ele alınması gerekir. Aslında yazıyı oluştururken hedef kitleyi ve onların özelliklerini düşünmenin gerekli olduğunu bilmek, öğrencilerin yazma öncesi ve sırasında kendi anlatımlarını sürekli olarak gözden geçirmelerini sağlar. Bu durum da "hazırlık"ın ilk aşamalarında açığa çıkarılan malzemenin nasıl kullanılacağını belirler. Görüldüğü gibi yazı türünün ve hedef kitlenin belirlenmesi, iç içe ele alınabilecek ve birbirini etkileyen unsurlardır. Bir yazıyı yazma sürecinde "hazırlık" basamağının farklı boyutları olarak bu alt başlıklar hakkında öğrencilere bilgi vermek ve örnekler göstermek, çalışmalara bu kapsamda devam etmek, zaman içerisinde öğrencilerin yazılı anlatım ürünlerinin kalitesini artıracaktır.

\section{Sonuç ve Öneriler}

Hayattaki en basit işlerden en karmaşık işlere kadar her faaliyetin, kendi içinde bazı basamakların belirli bir düzen dâhilinde bir araya gelmesiyle oluştuğu görülür. İçinde hem bilişsel hem duyuşsal hem de devinişsel boyutlar barındıran "yazma" becerisinin geliştirilmesi, bu özelliğinden dolayı yoğun ve uzun süreli çalışmalar gerektirir.

Yazma becerisinin kazandırılması hususunda geçmişten günümüze hep sıkıntılar yaşanmaktadır. Bu durum ilkokuldan üniversiteye hatta üniversite sonrası iş hayatında kendini göstermektedir. Bu sonuç yazma becerisinin eğitimiyle ilgili sorunların olduğu anlamına gelmektedir.

Yazma öğretimi ile yazma becerisinin eğitimi, içerdikleri süreçler açısından birbirinden farklıdır. Yazmanın öğretiminden sonraki aşamalarda her sınıf seviyesine uygun olarak cümle kurma becerisinin geliştirilmesinden metin oluşturmaya doğru bir gelişim söz konusudur.

Yazılı anlatım becerisinin geliştirilmesinde eğitim çalışmalarının, becerinin alt boyutları göz önünde bulundurularak hayata geçirilmesi "süreç temelli yaklaşım"ın merkezinde yer alır. Ayrıca, süreci oluşturan her basamak da kendi içinde farkı beceriler içermektedir. Süreç temelli yazmanın ilk ve belki de en önemli basamağı olan "hazırlık" da kendi içinde alt boyutlardan oluşmaktadır. Yazma konusunun belirlenmesiyle başlayan, konuyla ilgili zihinde var olan birikimin açığa çıkarılması için düşünme ve fikir üretmeyle devam eden; ardından da konuyu sınırlandırma, yazma amacını, yazı türünü ve hedef kitleyi belirleme ile son bulan bu alt boyutların her biri kendi içinde önemlidir. Bu alt boyutların, özellikle Türkçe öğretmenleri tarafından ele alınması, yazma becerisinin doğasında olan aşamalı gelişimin öğrencilerde görülmesi açısından da büyük önem arz etmektedir.

Araştırma kapsamında ortaya konulan öneriler şunlardır:

Süreç temelli yazma eğitiminin her bir basamağı kendi içinde ayrıntılı olarak ele alınmalıdır. Bu şekilde, yapılacak eğitim çalışmaları daha somut bir hâle gelecek ve bu da uygulayıcılar olan öğretmenlerin işini kolaylaştıracaktır.

Yazma sürecinin her bir basamağı kendi içinde hem bağımsız hem de birbiriyle ilişkili bir şekilde ele alınmalı, bu süre zarfında öğrencilere basamaklar arasındaki ilişkilerin kavratılmasına yönelik çalışmalar yaptırılmalıdır.

Hazırlık basamağının verimli bir şekilde uygulanabilmesi için öncelikli olarak konu seçimine dikkat edilmeli, konu seçiminde öğrenciye görelik ilkesi göz önünde bulundurulmalıdır.

Hazırlık çalışmalarının ilk örneklerinde öğretmenler hazırlığı; "sesli düşünme yöntemi"ni kullanarak sınıfta öğrencilerin karşısında ve onlar yokmuş gibi, bu süreçte karşılaşılabilecek çeşitli durumları da örneklendirerek yapmalıdırlar. Bu uygulama, süreci öğrencilerin gözünde tam olarak somutlaştıracak; kendi yazma süreçlerinde, öğretmenin hazırık sırasında yaşadığı durumlarla karşılaştıklarında bunun normal olduğunu fark etmelerini sağlayacaktır.

Bu çalışma kapsamında ele alınan örnekler, eğitim-öğretim faaliyetleri sürecinde Türkçe öğretmenleri tarafından çeşitlendirilip detaylandırılmalıdır. Ayrıca uygulamalar sırasında hayata geçirilen iyi örneklerin paylaşıması yazma becerisinin eğitimi çalışmalarındaki başarıyı yükseltecektir. 


\section{Kaynaklar}

Ağca, H. (1999). Yazılı Anlatım. Ankara: Gündüz Eğitim ve Yayıncılık.

Akbaba, R. S. ve Ayaz, H. (2017). Süreç temelli yazma yaklaşımı ile ilgili yapılan çalışmalara ilişkin bir derleme. Researcher: Social Science Studies, S.9, 344-361.

Arıcı, A. F. (2008). Üniversite öğrencilerinin yazılı anlatım hataları. Uludağ Üniversitesi Eğitim Fakültesi Dergisi, 21(2), 209-220.

Ashman, A. E., Wright, S. K. and Conway, N. F. (1994). Developing the metacognitive skills of academically gifted students in mainstream classrooms. Roeper Review, 16(3), 198-204.

Asiltürk, B. (2017). Yazılı anlatım, metin inceleme ve oluşturma. İstanbul: ikaros Yayınları.

Aydoğdu, Ü. R., Karamustafaoğlu, O. ve Bülbül, M. Ş. (2017). Akademik araştırmalarda araştırma yöntemleri ile örneklem ilişkisi: doğrulayıcı doküman analizi örneği. Dicle Üniversitesi Ziya Gökalp Eğitim Dergisi, 30, 556-565.

Bahşi, N. (2018). Ortaokul öğrencilerinin yazma düzeyleri ve yazılarında karşılaşılan sorunlar. İnönü Üniversitesi Eğitim Bilimleri Enstitüsü, Yayımlanmamış Doktora Tezi.

Başgöz, ì. (2017). Gemerek nire Bloomington nire. İstanbul: Türkiye İş Bankası Kültür Yayınları.

Becker, H. S. (2015). Sosyal bilimcilerin yazma çilesi. Ankara: Heretik Yayınları.

Burdurlu, i. Z. (1984). Sözlü ve yazılı anlatım eğitimi. Yeni Defne, S.34, 11-16.

Canıtezer, A. (2014). 8. sınıf öğrencilerinin yazma motivasyonu ile yazııı anlatım beceri düzeyleri üzerine bir araştırma. Necmettin Erbakan Üniversitesi Eğitim Bilimleri Enstitüsü, Yayımlanmamış Doktora Tezi.

Clark, R. P. (2017). Yazma uğraşı. (Çev.: Banu Karakaş). İstanbul: Metropolis Yayıncılık.

Doğan, Y. (2018). Türkçe öğretmenlerinin kullandıkları yazma konuları. Prof. Dr. Alemdar Yalçın Armağanı. Ankara: Akçağ Yayınları.

Duman, B. (2007). Süreç temelli öğrenme-öğretim modeli. Muğla Üniversitesi Sosyal Bilimler Enstitüsü Dergisi, S.19.

Durukafa, G. (1992). Cluster metodu-yaratıcı kompozisyon. Gazi Eğitim Fakültesi Dergisi, 8(3), 83-114.

Emig, J. (1977). Writing as a mode of learning. College Composition and Communication, 28(2), 122128.

Emir, S. (1986). Kompozisyon yazma sanatı. İstanbul: Türk Dünyası Araştırmaları Vakfı Yayını.

Ertan, A. (1942). Yazma sanatı hakkında ögütler. İstanbul: Semih Lûtfi Kitabevi.

Flower, L. and Hayes, J. R. (1981). A cognitive process theory of writing. College Composition and Communication, 32(4), 365-387.

Göğüş, B. (1978). Orta dereceli okullarımızda Türkçe ve yazın eğitimi. Ankara: Kadıoğlu Matbaası.

Gökşen, E. N. (1964). Yazılı anlatımda plân, başlangıç ve sonuç. Türk Dili Dergisi, S.150, 352-354.

Gözler, H. F. (1974). Örnekleriyle temel kompozisyon bilgileri. İstanbul: İnkılâp ve Aka Kitabevi.

Guitton, J. (1968). Düşünme sanatı. (Çev.: Cevdet Perin). İstanbul: Remzi Kitabevi.

Henry, L. H. (1986). Clustering: writing (and learning) about economics. College Teaching, 34(3), 89-93.

Hertman, A. E. (2006). Derleme makale yazımında, konferans ve bildiri sunumu hazırlamada pratik bilgiler. Hemşirelikte Eğitim ve Araştırma Dergisi, 3(1), 2-4.

Janssen, D., Van Waes, L. and Van den Bergh, H. (1996). Effects of thinking aloud on writing processes. In: The science of writing: theories, methods, individual differences, and applications. (Edit. Levy C. Michael and Ransdell, Sarah). Mahwah, N. J., Lawrence Erbaum, p.233-250.

Kantemir, E. (1972). Yazılı ve sözlü anlatım. Ankara: Sevinç Matbaası, Ankara Üniversitesi Eğitim Fakültesi Yayınları.

Karaalioğlu, S. K. (Tarihsiz). Sözlü/yazılı kompozisyon konuşmak ve yazmak sanatı. 29. Baskı, İstanbul: İnkılâp Kitabevi.

Karatay, H. (2011). Süreç temelli yazma modelleri: planlı yazma ve değerlendirme. Yazma eğitimi. (Ed.: Murat Özbay), Ankara: Pegem Akademi Yayınları.

Kasapoğlu, B. (2007). Türkiye ve Almanya'da ilköğretim birinci kademe dördüncü sınıf ana dili ders kitaplarında yazma eğitimi ve öğretimi. Marmara Üniversitesi Eğitim Bilimleri Enstitüsü, Yayımlanmamış Doktora Tezi.

Kavcar, C., Oğuzkan, F. ve Sever, S. (1997). Türkçe öğretimi. Ankara: Engin Yayınevi. 
Kaya, T. (1998). Türkçe öğretiminde çocuk edebiyatının yeri. A.Ü. TÖMER Türkçe'nin Öğretimi ve Eğitimi Sempozyumu Bildirileri, Gaziantep.

Kurudayıŏlu, M. ve Karadağ, Ö. (2010). İlköğretim öğrencilerinin yazılı anlatımlarının konu seçimleri açısından incelenmesi. Mustafa Kemal Üniversitesi Sosyal Bilimler Enstitüsü Dergisi, 7(13), 192207.

Küçük, S. (2006). Türkçe öğretiminde yazılı anlatım çalışmalarının sorularla yönlendirilmesi. Türk Eğitim Bilimleri Dergisi, 4(2), 181-198.

Maltepe, S. (2006). Türkçe öğretiminde yazılı anlatım uygulamaları için bir seçenek: yaratıcı yazma yaklaşımı. Dil Dergisi, S.132, 56-66.

MEB. (2013). Gıda teknolojisi, tereyağ. (Bireysel öğrenme materyali) Ankara.

MEB. (2018). Yazarlık ve yazma becerileri dersi öğretim programı. Ankara: Millî Eğitim Bakanlığı Yayınları.

MEB. (2019). Türkçe dersi öğretim programı. Ankara: Millî Eğitim Bakanlığı Yayınları.

Murray, D. M. (1978). Write before writing. College Composition and Communications, 29(4), 375-381.

Oğuzkan, T., Öz, M. F., Demiray, K. ve Özdemir, E. (1972). ilkokuma öğretmen kılavuzu. Ankara: Millî Eğitim Basımevi.

Okurer, C. (1967). Kompozisyon öğretimi bakımından Ingiltere maarifi hakkında bir inceleme. İstanbul: Millî Eğitim Basımevi.

Özbay, M. (2000). ilköğretim okulu öğrencilerinin yazılı anlatım becerileri. Ankara.

Özdamar, K. (2003). Modern bilimsel araştırma yöntemleri. Eskişehir: Kaan Kitabevi.

Özdemir, E. (1967). Örnekli ve uygulamalı yazma tekniği. Ankara: Üçler Yayını.

Özön, M. N. (1961). Yazmak sanatı ve kompozisyona giriş. İstanbul: Remzi Kitabevi.

Raimes, A. (1980). Writing and learning across the curriculum: the experience of a faculty seminar. College English, 41(7), 797-801.

Rohman, D. G. (1965). Pre-writing the stage of discovery in the writing process. College Composition and Communications, 16(2), 106-112.

Sarar Kuzu, T. ve Soytürk, E. (2019). Ortaokul kompozisyon yazma çalışmalarının metindilbilimin metin üretim evreleri açısından değerlendirilmesi. Uluslararası Çocuk Edebiyatı ve Eğitim Araştırmaları Dergisi, 3(1), 12-29.

Tansel, F. A. (1963). iyi ve doğru yazma usûlleri, Il. kompozisyon. Ankara: Millî Kültür Yayınları.

TDK. (2005). Türkçe sözlük. Ankara: Türk Dil Kurumu Yayınları.

Tekin, H. (1980). Okuduğunu anlama gücü ile yazılı anlatım becerisini gelişstirme yönünden okullarımızdaki Türkçe öğretimi. Ankara: Gül Yayınevi.

Tekşan, K. (2001). Yazıı anlatımı geliştirmede ön hazırlığın etkisi. Çanakkale Onsekiz Mart Üniversitesi Eğitim Bilimleri Enstitüsü, Yayımlanmamış Doktora Tezi.

Temizkan, M. (2003). Yazılı anlatım etkinliği çerçevesinde Türkçe öğretmenlerinin çalışmalarına ilişkin bir değerlendirme. Hatay Mustafa Kemal Üniversitesi, Yayımlanmamış Yüksek Lisans Tezi.

Temizkan, M. (2014). Yaratıcı yazma süreci. Ankara: Pegem Akademi Yayınları.

Van Someren, M. W., Barnard, Y. F. and Sandberg, J. A. C. (1994). The think aloud method. London: Published by Academic Press.

Vygotsky, L. S. (1998). Düşünce ve dil. (Çev.: S. Koray), İstanbul: Kaynak Yayınları.

Warriner, J. E. (2004). Warriner's high school handbook. Canada: Holt, Rinehart and Winston, Inc.

Yalçın, A. (2018). Son bilimsel gelişmeler ışığında Türkçenin öğretim yöntemleri. Ankara: Akçağ Yayınları.

Yalçın, S. D. (1998). Yazma eğitiminde yeni bir araştırma alanı: yaratıcı yazarlık. A.Ü. TÖMER Türkçe'nin Öğretimi ve Eğitimi Sempozyumu Bildirileri, Gaziantep.

Yıldız, C., Okur, A., Arı, G. ve Yılmaz, Y. (2013). Türkçe öğretimi. (Ed.: Cemal Yıldız), Ankara: Pegem Akademi Yayınları.

Yılmaz, Ö. (1998). Orta öğretimde yazılı anlatım. A.Ü. TÖMER Türkçenin Öğretimi ve Eğitimi Sempozyumu Bildirileri, Gaziantep.

Zorbaz, K. Z. (2010). Illköğretim okulu öğrencilerinin yazma kaygı ve tutukluğunun yazılı anlatım becerileriyle ilişkisi. Gazi Üniversitesi Eğitim Bilimleri Enstitüsü, Yayımlanmamış Doktora Tezi. 


\section{Introduction}

\section{Extended Summary}

Language is a tool consisting of listening/monitoring, speaking, reading, and writing skills and people use this tool in all kinds of communication activities. Among these skills, speaking and writing are called expressive skills. Studies to improve speaking and writing skills aim to provide students with the ability to explain what they see, experience, hear, and think correctly, purposefully, and effectively.

Writing offers many multiple possibilities such as understanding life, thinking, discovering, stepping oneself in a topic, and expressing all of these. There seems to be a close relationship between writing and thinking. It is necessary to work intensively and for a long time in order to be successful in writing, which has many interwoven sub-dimensions. Also, the knowledge which one gained on successful writing is important.

It is a difficult task to improve students' writing skills, which has an important place both in daily life and in business life. Therefore, there are difficulties in the improving of this skill from past to present. However, like any skill, writing is a skill that can be improved through teaching. In this context, students' writing skills can be improved by planning appropriate writing activities for the target audience and applying them in the long term.

In the process of improving students' writing skills, it is necessary to differentiate between "writing training" and "teaching writing". Writing training corresponds to the process in which the mechanical aspect of writing is taught in the first year of primary school. Teaching writing, on the other hand, refers to the works done to explain feelings, thoughts and wishes along with what is seen and heard correctly, properly and effectively by using the possibilities of language.

In order to achieve success in written expression, the application of a process-based writing approach has been an important issue, especially in recent years. In this process, which involves preparation, creating a draft of writing, reviewing the draft, correcting the writing, sharing the writing, preparation is the first step and it is important because it forms a basis for other steps. Therefore, the preparation step needs to be discussed in detail.

Preparatory studies can be handled in two ways, short-term and long-term. Short-term preparatory studies are motivating, engaging and guiding studies, which are carried out in five to ten minutes before writing. In this research, "preparation" is considered as short-term preparation. In this context, preparation is discussed in terms of following subheadings: determining the topic, thinking and generating ideas on the topic, limiting the topic and determining the purpose of writing, determining the type of text and determining the target audience.

\section{Method}

This article is a review article. In review articles important studies published on the topic are classified and evaluated. Thus, the topic of the research is defined and explained in detail and determinations are made on the topic. Then these are associated with the author's background. In this research, books, articles and theses which are on teaching writing in general and process-based writing in particular are examined and the sub-dimensions of the "preparation" phase in the process-based writing approach are discussed. In addition, examples that Turkish language teachers can use in preparation studies are presented.

\section{Result and Discussion}

Improving students' writing skills has been always problematic from past to present. This situation manifests itself in all levels of education from primary school to university.

Teaching writing skill should be handled in the long-term because improving this skill is difficult. Therefore, planning teaching activities according to the process-based writing approach is benefical. In order to make this planning, Turkish teachers and preservice teachers should have knowledge about the subject. Within this framework, it is important to examine the sub-dimensions of the process-based writing approach and to share the examples.

When "preparation", which is the first step of the process-based writing approach, is discussed with its sub-dimensions, it can be thought that the studies will be more efficient. In addition, the 
studies carried out at this stage will directly affect the efficiency of other stages of the process. These sub-dimensions should be taken into consideration in every writing task in order to carry out the studies in the preparation step efficiently. Also, awareness of students should be raised by giving feedback during teaching writing.

Modelling the tasks in the preparation step by the teacher helps students to understand the issues that are abstract for them. At this stage, the teacher should provide valuable examples of the application of the sub-dimensions of the preparation process for the students by thinking aloud method. As in all language skills, the detailed and long-term studies in the teaching of writing skill should be considered as one of the most important issues in achieving the goals. 